\title{
Supplying the wildlife trade as a livelihood strategy in a biodiversity hotspot
} $\underline{\text { Janine E. Robinson }}^{1}, \underline{\text { Richard A. Griffiths }}^{1}, \underline{\text { Iain M. Fraser }}^{2,3}, \underline{\text { Jessica Raharimalala }}^{4}, \underline{\text { David L. Roberts }}^{1}$ and Freva A. V. St. John $^{1,5}$

\begin{abstract}
Much of the global wildlife trade is sourced from biodiversity-rich developing countries. These often have high levels of poverty and habitat loss, particularly in rural areas where many depend on natural resources. However, wildlife collection may incentivize local people to conserve habitats that support their livelihoods. Here we examined the contribution of the commercial collection of live animals to rural livelihoods in Madagascar, one of the world's most important biodiversity hotspots. Using questionnaires, we investigated the prevalence, profitability relative to other livelihood activities, and local importance of the trade, and its capacity to provide incentives for conservation. Thirteen percent of households were engaged in live animal collection in the study area $(\sim 5 \%$ trapped reptiles and amphibians and the remainder trapped invertebrates). This formed part of a diverse livelihood strategy, and was more profitable than other activities (in terms of returns per unit of effort), with median earnings of $\sim$ US $\$ 100$ per season ( $25 \%$ of Gross National Income per year). However, trapping was part-time, usually undertaken by poorer members of the community, and often perceived as opportunistic, risky, and financially unreliable. Further, trappers and nontrappers held similar perceptions regarding conservation, suggesting wildlife trade currently does not incentivize enhanced stewardship of traded species and their habitats. Our study brings together a range of methodologies to present the most comprehensive insights into livelihoods and conservation in poor rural communities involved in the commercial collection of live animals to supply international trade. This improved understanding of the wider socioeconomic dimensions of wildlife trade can inform policy and management interventions for both the threats and opportunities associated with global trade in biodiversity both in Madagascar and more generally.
\end{abstract}

Key Words: amphibians; CBD; CITES; conservation; livelihoods; Madagascar; reptiles

\section{INTRODUCTION}

Millions of animals, plants, and their products, are traded annually, both legally and illegally, to supply domestic and international markets (Broad et al. 2003). Much of this trade occurs in biodiversity-rich developing countries where people depend on natural resources (Robinson and Redford 1991), and where sustainable and legal use of wildlife can support livelihoods (Roe et al. 2002). Indeed, international agreements such as The Convention on Biological Diversity (CBD) promotes sustainable use of biological diversity and recognizes rights of people to benefit from their use (CBD 2014). However, unsustainable and illegal wildlife trade threatens wildlife populations (Kenney et al. 1995), has detrimental environmental and health related impacts (Vitousek et al. 1996, Karesh et al. 2005), and in some cases has become highly militarized threatening human security (Duffy et al. 2015).

A key framework regulating international wildlife trade is The Convention on International Trade in Endangered Species (CITES), a global agreement aiming to ensure wildlife trade is sustainable (CITES 2016). Species are listed on appendices offering varying levels of protection, with trade regulated and monitored via a permitting system. However, capacity and resources to implement and enforce CITES is often inadequate (Rosen and Smith 2010, Bennett 2011) and enforcement alone can be problematic (Cooney and Jepson 2006, Challender and MacMillan 2014). Consequently, conservationists advocate alternative strategies to regulate wildlife trade including incentivizing local communities, demand mitigation, and examining sustainable off-take mechanisms, e.g., wildlife farming (Challender and MacMillan 2014, Roe et al. 2015). Incentivebased programs, such as integrated conservation and development programs and payments for ecosystem services, aim to reconcile conservation and development so that mutual benefits can be realized (Spiteri and Nepalz 2006). Where local stakeholders benefit directly from a resource, they may have an incentive to protect it, leading to environmental stewardship (Salafsky and Wollenberg 2000). Although sustainable and wellmanaged extractive use of resources can deliver positive livelihood outcomes and promote incentives for conservation (Gordon and Ayiemba 2003, Hutton and Leader-Williams 2003), many projects have not realized their goals (Kusters et al. 2006, Lybbert et al. 2011).

Clearly, when addressing the incentives and motivations of different actors involved in wildlife trade, it is important to engage local communities (Roe et al. 2015, Duffy et al. 2016). A thorough understanding of the social and economic dimensions of wildlife trade supply chains allows evaluation of who will be affected (and by how much) by policy and management interventions aiming to regulate trade, and informs conservation interventions. Additionally, socioeconomic characteristics of target communities have been shown to impact the success of conservation projects (Chukwuone 2009). Although previous studies have sought to understand socioeconomic determinants of bushmeat trade and wild food consumption in rural areas (Fa et al. 2002, de Merode et al. 2004, Coad et al. 2010, Kümpel et al. 2010, SchulteHerbruggen et al. 2013), few have explored livelihoods associated with commercial supply of wildlife in exporting countries to supply the exotic pet trade (but see Gordon and Ayiemba 2003, Rabemananjara et al. 2008, Jepson et al. 2011), particularly at the harvesting stage where people arguably have the most direct impact on natural resources. This may seem far removed from retail outlets in consumer countries where discussions frequently

${ }^{1}$ Durrell Institute of Conservation and Ecology, School of Anthropology and Conservation, University of Kent, ${ }^{2}$ School of Economics, University of Kent, ${ }^{3}$ Department of Economics and Finance, La Trobe University, ${ }^{4}$ Madagasikara Voakajy, ${ }^{5}$ School of Environment, Natural Resources and Geography, Bangor University 
focus on animal health, welfare, and ecological consequences of trade (Chomel et al. 2007, Carrete and Tella 2008, Baker et al. 2013) and little is known about the livelihoods of those involved in collection.

Madagascar is a biodiversity hotspot with high concentrations of endemic species (Myers et al. 2000), and is one of the poorest countries in the world, with a Human Development Index of 0.520 (ranked 154 of 185 countries; UNDP 2015). Madagascar has lost much of its original forest with slash and burn agriculture, along with fuelwood cutting representing the most significant threats to its biodiversity (Harper et al. 2007). Madagascar has a rich wildlife trade, particularly reptiles and amphibians, which are exported live to supply international herpetofauna markets (Carpenter and Robson 2008). It was the dominant exporting country of the world's chameleon trade in the early 1990s, with a global market share of $\sim 40 \%$, and its trade in golden mantella frogs (Mantella aurantiaca) peaked at 32,000 individuals in 1998 (Rabemananjara et al. 2008). Despite the trade decreasing since the 1990s (Carpenter et al. 2004, Rabemananjara et al. 2008), Madagascar remains one of the largest global exporters of live CITES-listed amphibians (UNEP-WCMC 2018) and exports $2.5 \%$ of the global commercial trade in live CITES Appendix II reptiles (Robinson et al. 2015). Madagascar joined CITES in 1975, and has export quotas for a number of species permitted in trade.

Using Madagascar as a case study, we analyzed the contribution of legal live animal collection to rural livelihoods in villages at the source of the trade to understand the local value and importance of this activity. We estimate the proportion of households engaged in wildlife collection; determine how it contributes to the livelihood portfolio; compare its profitability to other livelihoods; and investigate the perceptions of trappers and nontrappers toward traded and nontraded animals to explore the potential for trade to act as an incentive for conservation. Given the global importance of Madagascar's herpetofauna and its popularity in international markets, we provide some focus on reptiles and amphibians as a traded commodity. To our knowledge, this is the first study providing a detailed analysis of the relative importance of the collection of live animals supplying the pet trade, to the livelihoods of rural people.

\section{METHODS}

\section{Study area}

Our research was conducted in the Moramanga district of the Alaotra-Mangoro region of Madagascar (Fig. 1). Moramanga is located on a plateau between the central highlands (and the capital city Antananarivo), and the east coast. The district is subdivided into several communes, each representing a collection of villages, mostly rural except for the Moramanga urban center. The wildlife supply chain consists of exporters, middlemen, and local collectors (Rabemananjara et al. 2008, Robinson 2016). Preliminary interviews with government authorities, nongovernmental organizations, exporters, and intermediaries along the wildlife trade supply chain suggested Moramanga to be a hub for wildlife collection and trade. This is likely due to its proximity to Antananarivo (where most wildlife exporters are situated) and its position relative to the national road and biodiverse eastern rainforests.
Fig. 1. Moramanga district and study communes. Inset: position of Moramanga district in Madagascar.

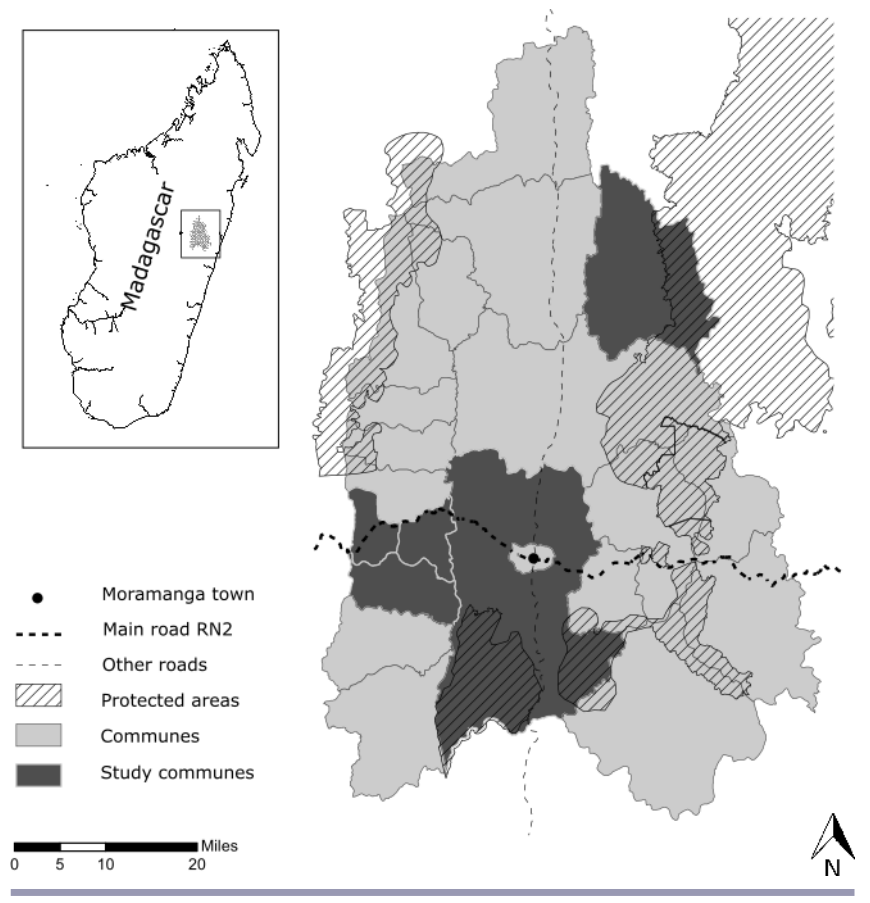

Ethical approval was granted by the School of Anthropology and Conservation, University of Kent. On arrival in communes, commune and village leaders were visited to discuss the research and explain that we were studying legal collection of wildlife for trade and its relation to local livelihoods. Local guides were recruited in each village. We informed respondents that taking part in the survey was voluntary and they could stop at any time. Consent was recorded via a tick box on the questionnaire and persons under 18 only interviewed with agreement of their parent or guardian.

\section{Sampling}

We used two sampling approaches: systematic household sampling in villages identified as having trappers; and snowball sampling of households involved in trapping reptiles and amphibians specifically because a priori, trapping households were considered hard to identify and rare. We used the systematic household sample to estimate the prevalence of wildlife collectors in the study area and collect detailed information on livelihood strategies. We used the snowball sample to maximize the number of reptile and amphibian trapping households in order to collect detailed information on this activity. Two questionnaires were used: a household questionnaire completed by all respondents; and a detailed trapper questionnaire completed by reptile and amphibian trappers (in addition to the household questionnaire).

\section{Systematic household sample}

Trapping is prohibited within protected areas and our study focused on legal collection of wildlife for trade, therefore we constrained research to villages outside of protected areas. Based on preliminary interviews, five rural communes (excluding Moramanga urban center) were identified as trapping areas. For 
each commune, a list of villages where trappers resided was generated and refined throughout the course of the study through discussion with traders, village leaders, guides, and during household questionnaires. We randomly selected two to four villages (depending on village size) per commune from this list (aiming for $\sim 60$ households per commune) to distribute effort across communes. Thirty percent of households per village were interviewed, with a maximum of 30 and minimum of 10 per village. On arrival in the village, households were mapped with assistance from guides. While walking in a zig-zag pattern, we surveyed every $n$th household according to village size. If the household head was unavailable, the interviewer returned when they were available. A household was defined as all persons who normally live together and eat from the same cooking pot/kitchen.

\section{Snowball sampling}

The household questionnaire asked respondents if they knew anyone who collected reptiles and amphibians for trade. If a trapper was identified within a household not selected for inclusion in the systematic household survey, that individual was located and asked to complete both questionnaires. If trappers were identified in neighboring villages (within study communes) not selected for inclusion in the study, where possible, these villages were visited to survey those trappers. We therefore attempted to interview most reptile and amphibians trappers in the five communes.

\section{Questionnaires}

Questionnaires were piloted in villages in the study area in February 2014 and refined prior to fieldwork (March to July 2014). Cost information was collected in Malagasy Ariary (MGA) and converted to US dollars (US\$) using an exchange rate of 1 US $\$=2335$ MGA valid at the time of research (XE 2016).

The household questionnaire collected information on demographic attributes, livelihood activities, assets/wealth, perceptions, and knowledge of wildlife and wildlife trade. We asked respondents to list all household livelihood activities. To provide a measure of the perceived importance of trapping live animals compared with other activities, respondents then ranked these in order of importance to their own household for (1) income and (2) food. The most important activity was given a score of one, the second most important given a score of two, and so on. Activities not considered important were given a score of zero.

Household livelihood return (HLR) defined as the median amount of profit earned (US\$), per unit of time (1 hour) was calculated for each livelihood activity in order to compare their relative profitability (in terms of returns per unit of effort). For agricultural activities, we asked respondents about time spent doing the activity (months/days/hours), revenue (including market price and percentage of produce sold each year), and costs (excluding fixed costs, e.g., land purchase). For wildlife trade, we asked respondents about the collection period (months per year), number of orders per period, time taken to complete order (days), money received per order, and associated costs (see Appendix 1). By focusing on activities households currently engaged in rather than historical activities, we aimed to minimize recall bias. We also verified price information by collecting market price data from village/commune leaders.
To measure wealth, we used a standard asset bundle of 26 items as a comparative proxy of wealth, converted into a Household Asset Index (HAI) following Morris et al. (2000; Appendix 1). To investigate perceptions toward wildlife, we asked respondents a series of questions on a three or four point scale. We used several animal groupings with photographs representing traded and nontraded groups, including chameleons, geckoes, frogs, invertebrates, birds, lemurs, and tenrecs. Respondents were asked whether they perceived different groups important for income $(1=$ disagree, $2=$ neither agree nor disagree, $3=$ agree $)$ and whether they thought the numbers of the animals in the wild, and the amount of habitat, should be eliminated, reduced, maintained at the same level, or increased. To investigate factors influencing engagement in trapping, we asked respondents whether they were afraid of different animal groups, based on the hypothesis that fear of animals may be related to trapping.

The trapper questionnaire collected detailed information on reptile and amphibian trapping, the trade network, and collection practices. While the household questionnaire was completed by the household head, the trapper questionnaire was completed by trappers themselves in order to gain their perspective. However, in all but one case, the trapper was the household head.

\section{Data analysis}

Data analysis was conducted in R (R Core Team 2015). We used nonparametric tests ( $\chi^{2}$, Mann Whitney) to investigate differences in household size, education, time lived in village, number of household livelihood activities, and differences in perceptions regarding wildlife and habitats between trapping and nontrapping households. We used a Linear Model (LM) to investigate predictors of household wealth including engagement in different livelihood categories such as wildlife trapping, hunter-gathering, farm labor and nonfarm labor, education, migration, and number of working members in the household. We used a Generalized Linear Model (GLM) with binomial error structure to investigate predictors associated with trapping households, including wealth, age, migration, education, household size, engagement in huntergathering, and fear of wildlife. We numerically coded responses to scale questions regarding how afraid people were of different animals, and averaged for each person across different animal groups, to create a "mean fear" score for use in the GLM. Exploratory analysis including graphical inspection, correlation matrices, and bivariate tests were performed, and Variance inflation factors (VIFs) were used to test for collinearity among explanatory variables. For model selection, we used a model averaging-approach (Burnham and Anderson 2002, Symonds and Moussalli 2011) using the MuMIn package (Barton 2011). The model set included all variable combinations of the predictors listed in Tables 1 and 2. Prior to model averaging, models were restricted to $\triangle \mathrm{AIC}_{\mathrm{c}}<4$ (corrected Akaike Information Criterion; Burnham and Anderson 2002). Averaged parameter estimates ( $\beta$ ), unconditional standards errors (SE), upper and lower $95 \%$ confidence intervals (UCI, LCI), p-values, and relative variable importance factors (RI) are reported after model averaging.

We calculated HLR for all livelihood activities where $>5 \%$ of households engaged in the activity, with the exception of huntergathering activities (data collection not set up to value produce from hunter-gathering) and "trading produce" (too variable due 
Table 1. Summary of averaged linear model (LM) fitted with normal errors to investigate predictors associated with household (HH) wealth in systematically sampled villages, in the Moramanga district of Madagascar.

\begin{tabular}{|c|c|c|c|c|c|c|c|}
\hline Response & Predictor & $\beta$ & SE & LCI & UCI & $\mathrm{P}$ & RI \\
\hline \multirow{9}{*}{$\begin{array}{l}\text { Asset Index } \\
N=211\end{array}$} & (Intercept) & 3.81 & 0.05 & 3.72 & 3.91 & $<0.001$ & \\
\hline & Farm labor: TRUE & -0.46 & 0.13 & -0.72 & -0.21 & 0.004 & 1.00 \\
\hline & No. working in $\mathrm{HH}$ & 0.32 & 0.10 & 0.13 & 0.51 & $<0.001$ & 1.00 \\
\hline & Education & 0.31 & 0.10 & 0.12 & 0.50 & 0.002 & 1.00 \\
\hline & Hunter-gatherer: TRUE & -0.24 & 0.10 & -0.44 & -0.04 & 0.018 & 0.96 \\
\hline & Trapper of animals: TRUE & -0.27 & 0.14 & -0.55 & 0.00 & 0.052 & 0.75 \\
\hline & No. cultivation activities & 0.08 & 0.10 & -0.12 & 0.28 & 0.415 & 0.28 \\
\hline & Nonfarm labor: TRUE & -0.03 & 0.10 & -0.23 & 0.16 & 0.745 & 0.19 \\
\hline & Migrant: TRUE & 0.05 & 0.16 & -0.26 & 0.36 & 0.762 & 0.19 \\
\hline
\end{tabular}

Averaged parameter estimates ( $\beta$ ), unconditional standards errors (SE), upper and lower confidence intervals (UCI, LCI), p-values, and relative variable importance factors (RI) are reported. The Akaike Information Criterion correction (AIC $_{\mathrm{c}}$ ) was used to rank models and model ranked $\Delta \mathrm{AIC}_{\mathrm{c}}$ $<4$ were averaged to obtain final estimates. Significant explanatory parameters, where confidence intervals do not cross zero, are in bold. Relative importance (RI) refers to the summed Akaike weights across all models in which the variables were present. Response variable (asset index) was log 10 transformed to improve model fit. "Farm labor," "hunter-gatherer," "nonfarm labor," "trapper of animals," and "migrant" were all binary variables, whereas "no. cultivation activities," "no. working members in HH," and "education" were treated as continuous variables.

to large range of products traded). However, "trading produce" is included in the ranking exercise that gives another measure of its relative importance as a livelihood activity. Therefore we prioritized HLR analyses to activities most commonly conducted, excluding activities very few households engaged in and for which data would have been less reliable because of low sample sizes. We calculated HLR for trappers of reptiles and amphibians (not all wildlife) because the trapper questionnaire was designed to collect this information. The following formula was used to calculate HLR:

\section{HLR=Net Revenue/Total Time}

where Net Revenue is the annual income, minus costs for that year and Total Time is the time in hours spent doing the activity over one year. We calculated HLR in two ways: HLR1 was calculated as if $100 \%$ of produce was sold therefore accounting for the subsistence value of this produce, whereas HLR2 incorporated percentage sold as indicated by respondents, giving a more reliable measure of actual monetary value obtained. HLR was calculated for each household and then the median value across all households calculated for each activity.

Because snowball sampling is a nonprobability technique, inferential statistics (including the LM, GLM, and MannWhitney U tests investigating perceptions toward traded wildlife) were conducted only on data collected via systematic sampling. For the following sections "reptile and amphibian collection as a livelihood," "HLR," and "barriers to engagement in reptile and amphibian collection," descriptive summary data are presented using households identified via both sampling approaches in order to maximize data on trapping as an activity.

\section{RESULTS}

\section{Wildlife trapping prevalence}

A total of 240 household questionnaires were completed through systematic sampling across 16 villages corresponding to an average of $33 \%$ of households per village. Nonresponse rate was $6 \%(n=12$, recorded in four of five communes). The systematic sample identified 32 (13.3\%) households currently involved in trapping live animals for trade. Thirteen (5.4\%) trapped reptiles and amphibians and the remaining 19 trapped invertebrates only (butterflies, stick insects, crickets, and scorpions).

We identified a further 21 trappers through snowball sampling incorporating an additional two villages. Of these, 17 trapped reptiles and amphibians (four trapped invertebrates only). In summary, 30 trappers of reptiles and amphibians were encountered across 18 villages in five communes, using both sampling approaches, 28 of which completed the trapper questionnaire. A total of 260 household questionnaires were completed using both sampling approaches.

\section{Household livelihood profile}

Households participated in a wide variety of livelihood activities (Appendix 2, Table A2.1). Six broad livelihood categories, each containing a number of subcategories, were identified including cultivation, livestock keeping, wildlife trapping (for trade), hunter-gathering, farm labor, and nonfarm labor. Farm labor involved working on other people's farms. Nonfarm labor included various forms of self-employment, e.g., doing laundry for others, and a few types of formal employment, e.g., teaching. Because of the informal nature of many of these jobs, it proved difficult to split this category up further.

Households engaged in a median of three of the six livelihood categories, and eight different individual activities. As expected, nearly all households engaged in cultivation (median of six crop types grown per household, interquartile range $[\mathrm{IQR}]=3$ ) and three-quarters $(77 \%)$ had livestock (median of two types of livestock per household, IQR =2). Households cultivated a diverse array of crops, cumulatively reporting 40 fruit and vegetable types including three rice production systems (lowland, irrigated, upland). Hunter-gathering was listed by a third of households and included collection of animals for food (tenrecs, shrimps, edible frogs and fish); collection of forest plants/fruits for food, medicine, and other uses; collecting firewood and honey; and making charcoal. Fifteen percent of households engaged in daily farm labor and nearly a third $(30 \%)$ in nonfarm labor (Appendix 2, Table A2.1). 
Table 2. Summary of averaged generalized linear model (GLM) with binomial error to investigate predictors associated with live animal trapping households $(\mathrm{HH})$ in systematically sampled villages, in the Moramanga district of Madagascar.

\begin{tabular}{|c|c|c|c|c|c|c|c|}
\hline Response & Predictor & $\beta$ & SE & LCI & UCI & $\mathrm{P}$ & RI \\
\hline \multirow{2}{*}{$\begin{array}{l}\text { Trapper/ } \\
\text { nontrapper }\end{array}$} & (Intercept) & -2.51 & 0.32 & -3.15 & -1.87 & $<0.001$ & \\
\hline & Family involved in WT: TRUE & 2.51 & 0.52 & 1.48 & 3.54 & $<0.001$ & 1.00 \\
\hline \multirow[t]{7}{*}{$N=209$} & Asset index & -1.95 & 0.91 & -3.74 & -0.15 & 0.033 & 1.00 \\
\hline & Hunter gatherer: TRUE & -1.15 & 0.55 & -2.23 & -0.07 & 0.036 & 0.91 \\
\hline & Mean fear & -0.69 & 0.50 & -1.68 & 0.29 & 0.167 & 0.48 \\
\hline & Age & -0.58 & 0.51 & -1.58 & 0.42 & 0.257 & 0.38 \\
\hline & Migrant: TRUE & 0.66 & 0.64 & -0.60 & 1.93 & 0.304 & 0.33 \\
\hline & Education & 0.02 & 0.51 & -0.99 & 1.03 & 0.968 & 0.18 \\
\hline & No. people in $\mathrm{HH}$ & 0.06 & 0.45 & -0.83 & 0.95 & 0.891 & 0.18 \\
\hline
\end{tabular}

Averaged parameter estimates ( $\beta$ ), unconditional standards errors (SE), upper and lower confidence intervals (UCI, LCI), p-values, and relative variable importance factors (RI) are reported. The Akaike Information Criterion correction ( $\mathrm{AIC}_{\mathrm{c}}$ ) was used to rank models and any model that ranked $\Delta \mathrm{AIC}_{\mathrm{c}}<4$ was averaged to obtain final estimates presented. Significant explanatory parameters, where confidence intervals do not cross zero, are in bold. Relative importance (RI) refers to the summed Akaike weights across all models in which the variables were present. "Family involved in WT" (wildlife trade), "hunter gatherer," and "migrant" were all binary variables. "Asset index," "age," "no. of people in household," and "education" were all treated as continuous variables. "Mean fear" was calculated by averaging the responses given to the Likert scale questions across the different wildlife groups: chameleons, geckoes, snakes, frogs, insects, birds, lemurs, and tenrecs, where the question "I am afraid of this animal" was asked and responses were coded as disagree $=1$, neither agree nor disagree $=2$, and agree $=3$.

There were no significant differences between wildlife trapping and nontrapping households according to household size $\left(\mathrm{U}_{208}\right.$, $\left.{ }_{32}=3410.5, \mathrm{p}=0.819\right)$, migration into the district $\left(\chi^{2}=0.010, \mathrm{n}\right.$ $=237, \mathrm{p}=0.921)$, years lived in village $\left(\mathrm{U}_{199,32}=3305, \mathrm{p}=0.730\right)$, or education level $\left(\chi^{2}=1.424, n=240, p=0.491\right.$; for demographic parameters see Appendix 3, Table A3.1).

The LM showed that increasing wealth, quantified using an Asset Index, was associated with decreasing participation in hunting and gathering and daily farm labor (Table 1). There was also indication of a negative association of wealth with wildlife trapping $(\beta=-0.27, p=0.052)$, but the $95 \%$ confidence intervals narrowly overlapped zero. Wealth was positively associated with an increasing number of working members in the household and education.

Results of the binary GLM investigating factors associated with trapping households revealed that having another family member involved in wildlife trade, e.g., as a trapper, intermediary, or exporter, significantly predicted involvement in wildlife trapping (Table 2). Hunter-gatherer households and wealth were both negatively associated with wildlife trapping.

\section{Reptile and amphibian collection as a livelihood}

Reptile and amphibian trapping was largely seasonal, usually conducted during the rains when animals were reportedly most abundant (most popular months: November to April, median no. months $=8, \mathrm{IQR}=4, \mathrm{n}=28$ ). The official collection season was 1 February to 30 April for herpetofauna, and all year for insects (Ministere de l'Environment 2006) but did not appear strictly adhered to. Respondents reported fulfilling between 2 and 24 orders in a season (median $=8, I Q R=11$ ) with each order taking one hour to two weeks (median 3.3 days, IQR $=3.1$ ). Collection sites took between five minutes and three days to reach, usually by foot, with 5 to 450 animals collected per order $($ median $=75$, $\mathrm{IQR}=110, \mathrm{n}=21$ ).

All reptile and amphibian trappers interviewed were male, with a median age of $41(\mathrm{IQR}=14, \mathrm{n}=28)$. Trappers had been engaged in the activity for a median of 19 years $(\mathrm{IQR}=14, \mathrm{n}=28)$ and stated a number of reasons for becoming involved, the largest proportion declaring monetary reasons $(37 \%, \mathrm{n}=10$; also see Appendix 4 for uses of income from wildlife trapping). Thirty percent $(n=8)$ were encouraged to trap by family or friends, $19 \%$ $(\mathrm{n}=5)$ were engaged directly by collectors, and four were specifically trained by researchers or people linked to animal parks/zoos.

\section{Household livelihood return}

Reptile and amphibian trapping was the most profitable activity in terms of returns per unit of effort (Fig. 2, Appendix 5 Table A5.1) equating to a median HLR of US\$0.70 per hour. Many of the other activities were widely conducted subsistence-based agriculture and yielded zero or low monetary profit, e.g. lowland rice and cassava, because minimal amounts of produce from these crops were sold in a given year. However, these crops often had significant value in terms of household consumption, were sometimes exchanged for labor, and were generally cultivated alongside a number of other crops. Even when accounting for the subsistence value by calculating total revenue as if $100 \%$ of produce was sold (HLR1), reptile and amphibian trapping remained the most profitable individual activity based on returns per unit of effort. Other activities such as cultivating pineapples and daily farm labor yielded higher median net income when comparing annual returns (US\$152 and US\$111, respectively; Fig. 2, Appendix 5 Table A5.1), but wildlife trapping was also relatively profitable on an annual basis yielding a median net income of US\$105 per person.

Among wildlife trapping households, trapping was ranked most important for income by the highest proportion of respondents (Fig. 3), corroborating results of the HLR analysis. The ranking exercise validated other patterns revealed in the HLR analysis, with many respondents ranking staple produce such as cassava and rice highly important for food, oxen of little importance for income or food (largely working animals), and pineapples and pigs of reasonably high importance for income. It also highlighted differences between the HLR calculations and perceived importance, including the rice plantations, perceived important 
Fig. 2. Household livelihood return (HLR2) and net income (2) for the nine most profitable livelihood activities (those where HLR2 > \$0.1 per hour). Unshaded boxes depict left hand axes "HLR2" and shaded boxes depict right hand axes "Net Income 2." Horizontal line shows median, box shows interquartile range, and the whiskers depict the maximum and minimum values. Those furthest to the left have the highest median HLR2. There are 12 other livelihood activities where HLR2 was $<\$ 0.1$ per hour not shown here (see Appendix 5, Table A5.1).

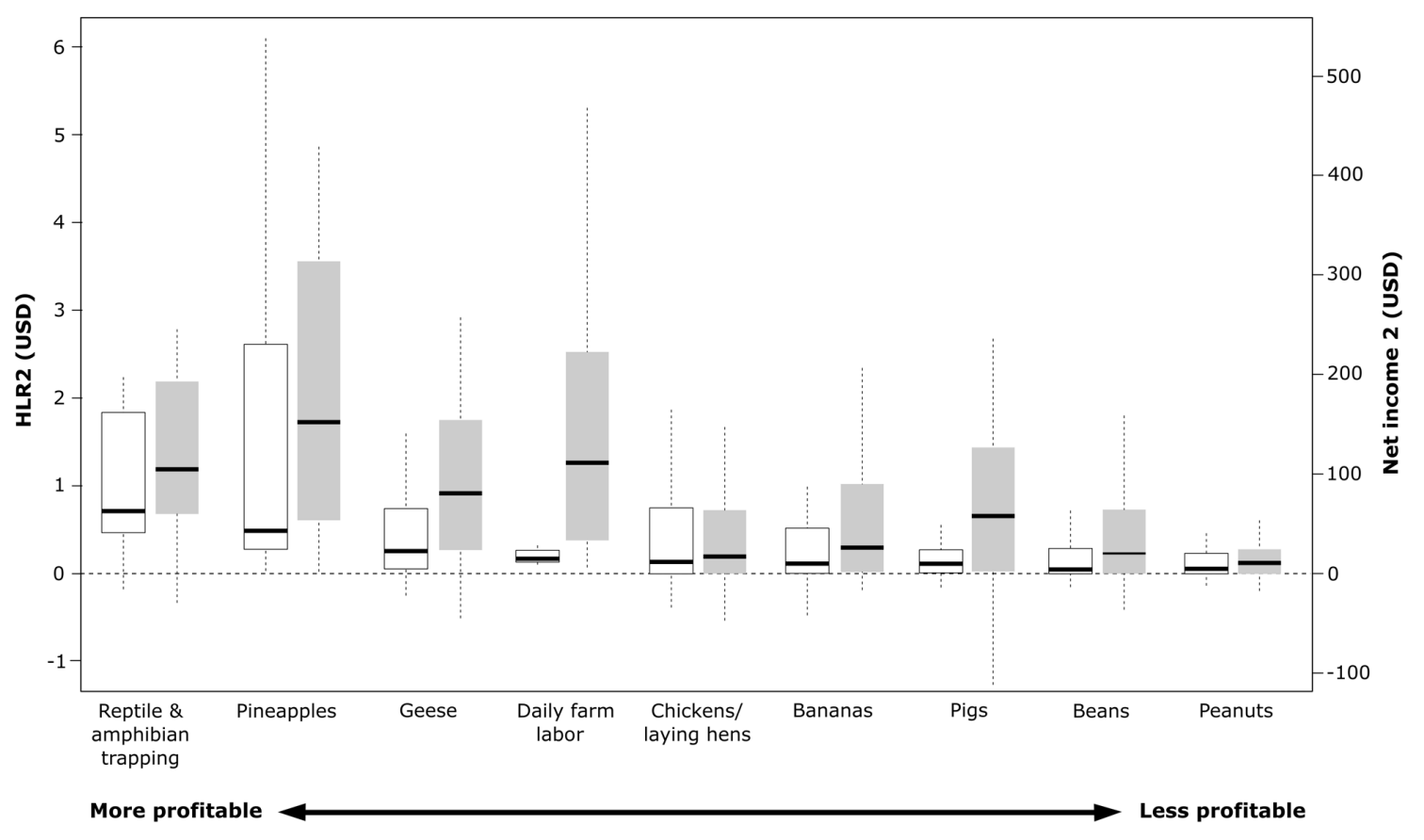

for income but not scoring highly in the HLR analysis. We were able to include "trading produce" in the ranking exercise for which HLR was not calculated, and this was ranked second most important for income.

\section{Barriers to engagement in reptile and amphibian collection}

Respondents cited a number of limitations to engaging in reptile and amphibian trapping, including weather (rain, cyclones, etc.) mentioned by $45 \%$ of trappers $(n=12)$ and limited orders or quotas referred to by $37 \%(n=10)$. Thirty percent reported illness as a limiting factor and $26 \%$ stated that it was limited by other activities, e.g., time needed to spend on plantations or studying. Four respondents $(15 \%)$ referred to low availability of animals during winter (including hibernation) and three respondents $(11 \%)$ commented there were fewer animals or habitat in general with one stating "the forest is destroyed, because of agriculture" and another stating "there are fewer geckoes in the wild."

Some trappers perceived the activity to be risky from a livelihood or economic perspective, with one stating "you never know if you will get orders" and another saying "I found stable work...and animal collection is not sure, you never know if you will get money or not." There was also concern regarding payments from intermediaries ("people dare to order and not pay") and regarding legal paper work. One trapper explained how he considered the job to be risky:

We trappers work in very hard conditions, we have to reach very far places, we work at night and barely sleep, it's a tiring job. There is no guarantee for our security... we also make a risky job compared with collectors and exporters, we work without legal paper...collectors bring legal papers when they buy animals from us.

Perceptions toward traded and nontraded animals

Respondents gave mixed views when asked how important different wildlife groups were for providing income, with slightly more people agreeing that frogs, chameleons, and geckoes were more useful than other groups (Appendix 6, Table A6.1). However, systematically sampled trappers were significantly more likely than nontrappers to agree that traded groups chameleons (Mann-Whitney $\left.\mathrm{U}_{205,31}=4471.5 \mathrm{p}<0.001\right)$, geckoes $\left(\mathrm{U}_{205,31}=\right.$ $4538 \mathrm{p}<0.001)$, snakes $\left(\mathrm{U}_{205,31}=3912.5, \mathrm{p}=0.02\right)$, frogs $\left(\mathrm{U}_{205,31}=\right.$ $4296.5, \mathrm{p}=0.001)$, invertebrates $\left(\mathrm{U}_{205.31}=4312, \mathrm{p}<0.001\right)$, and tenrecs (consumed locally; $\mathrm{U}_{205,31}=3823.5 \mathrm{p}=0.41$ ) were useful for income. There were no significant differences in how likely trappers or nontrappers were to agree that lemurs or birds were useful for income ( $p>0.05$ in both cases). Respondents were most afraid of invertebrates, snakes, and chameleons and least afraid of birds. However, trappers were significantly less afraid of invertebrates $\left(\mathrm{U}_{204,31}=2341.5, \mathrm{n}=0.001\right)$, and tenrecs $\left(\mathrm{U}_{205,31}=\right.$ $2430 \mathrm{p}=0.004)$ than nontrappers.

Although over $76 \%$ of respondents agreed that all wildlife groups were important for the environment (Appendix 6, Table A6.1), there were no differences between trapper and nontrapper opinions. Many respondents felt that chameleons (58\%), geckoes $(61 \%)$, snakes $(51 \%)$, frogs $(69 \%)$, invertebrates $(51 \%)$, birds $(72 \%)$, lemurs $(71 \%)$, and tenrecs $(70 \%)$ should be increased in 
Fig. 3. Respondents ranking of household livelihood activities in terms of importance for (a) providing income and (b) providing food. Shading indicates the proportion of respondents involved in the activity that ranked it as: $1=$ most important (darkest shading); 2 = second most important (second darkest shading); 3 = third most important (third darkest shading), 4+ (lightest shading). Data are sorted by the percentage of people that ranked livelihood activities as most important for providing income. Sample sizes are provided in brackets after the name of the livelihood activity (income, food). †We were able to include an additional activity "trading produce" in the ranking exercise for which it was not possible to calculate detailed household livelihood return.

(a) Income

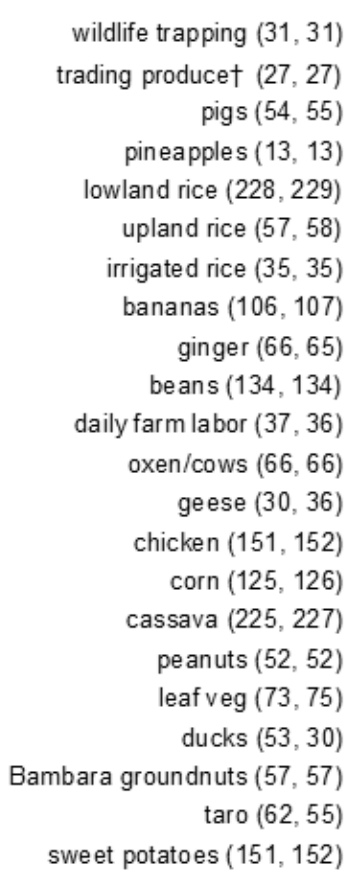

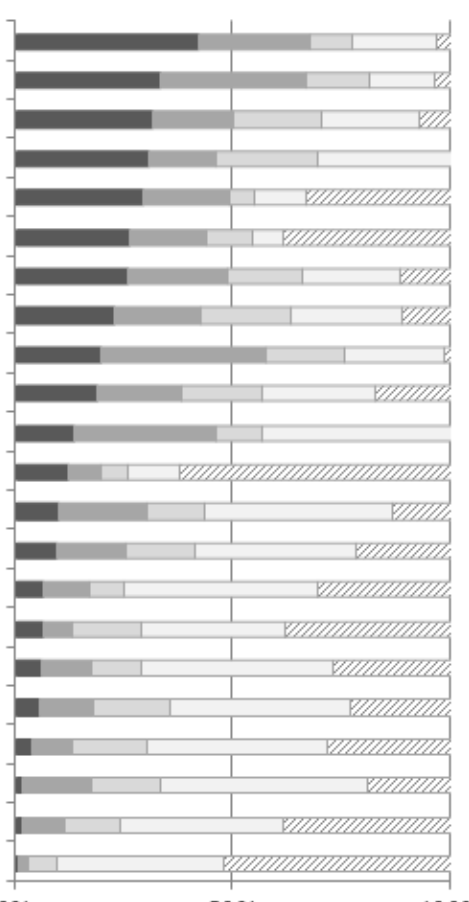

$0 \% \quad 100 \% \quad 0 \%$ (b) Food

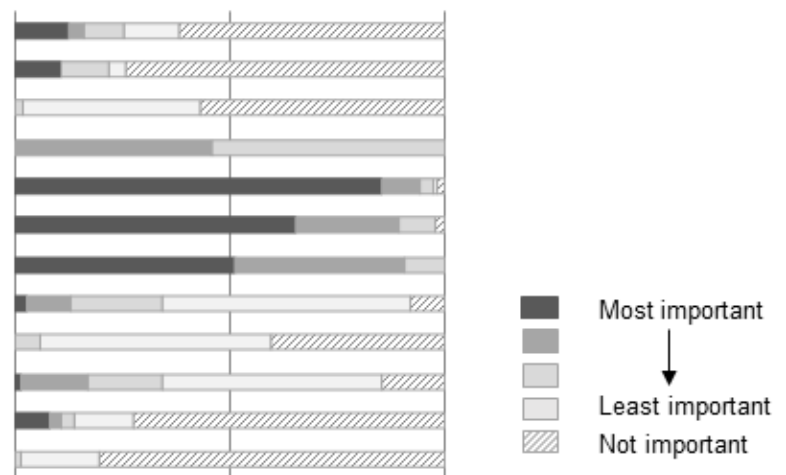

Proportion of respondents

the wild, rather than eliminated or reduced but again, there were no significant differences between trapper and nontrapper opinions. Additionally, over $66 \%$ felt that the amount of natural habitat should be increased ( $33 \%$ felt it should be kept at the same level, and $1 \%$ said it should be reduced), but there were no differences between trapper and nontrapper opinions.

\section{DISCUSSION}

Global trade in biodiversity is big business, and because collection from the wild usually involves local people, it can frequently make important contributions to livelihoods. Our study provides the first comprehensive analysis of livelihoods associated with commercial live animal collection, in a global biodiversity hotspot.

We estimated that $13 \%$ of households collected live animals for trade and $\sim 5 \%$ trapped reptiles and amphibians. If we extrapolate using the total number of households in the study villages, this equates to 110 households engaging in wildlife trapping as part of their livelihood strategy, and 45 trapping reptiles and amphibians within the 16 systematically sampled villages. We employed multiple approaches (systematic and snowball sampling) to identify trappers, allowing cross-validation of various sources of information, and through discussions with village leaders, guides, and respondents, we identified a total of 69 people potentially trapping reptiles and amphibians in the wider study area (including additional villages that were not systematically sampled within the five communes). However, despite visiting three villages, we could not verify the involvement of all 69 people, and suspect some may no longer be engaged in trapping. Indeed, $\sim 8 \%$ of systematically sampled households stated that they no longer trapped reptiles and amphibians for trade and we expect that engagement is somewhat fluid in response to fluctuations in supply, demand, and wider economic conditions. Occasionally, despite our survey being anonymous and investigating legal wildlife collection, some respondents were reluctant to discuss the topic (more so for reptiles and amphibians than for invertebrates), suggesting people may not have a thorough understanding of the rules associated with wildlife trade. Because our research team included local village guides, we were able to triangulate and verify much of the information provided concerning involvement in the trade. However, our estimate that $\sim 5 \%$ of households trapped reptiles and amphibians may be conservative. 
Wildlife collection forms part of a diverse livelihood strategy, and was part-time and opportunistic, carried out alongside other activities (predominantly agriculture). Indeed, diversification is considered the norm in rural Africa, with few people dependent on a single income source (Barrett et al. 2001). Equally, our models suggest that trapping may support some of the poorest households. Previous studies have documented that wild products often form an important risk-reduction strategy for rural poor in developing countries, supporting vulnerable households (Brashares et al. 2011). In terms of returns per unit of effort (HLR), trapping reptiles and amphibians proved relatively profitable, providing an important source of cash income. Trappers could earn a median income of US\$105 per year, whereas the 2015 Gross National Income (GNI) per capita in Madagascar was US\$420 (The World Bank 2016). Analyzing relative livelihood contributions in a meaningful way is complex, hence we compared profitability of different activities relative to each other, rather than make interpretations based on each household's complete livelihood portfolio. For example, we did not calculate HLR for activities that fewer than $5 \%$ of households engaged in, because of low sample sizes. Also, although trapping may be more profitable than individual crops, households frequently cultivated a variety of different crops and therefore the combined profit from farming may be higher overall. Although recall accuracy is a concern, prior-year recalls can be more accurate than shorter recall periods, particularly concerning rare or seasonal events (Golden et al. 2013). By focusing on current livelihood activities, which are mostly seasonal and/or rare, i.e., agriculture and wildlife trapping, steps were taken to minimize recall bias to provide a snapshot of household livelihood strategies. Additionally, Jones et al. (2008) showed that rapid assessment interviews with villagers in Madagascar can provide reliable information on harvesting activities.

The high relative profitability of wildlife trapping indicates that households could potentially earn income from trapping from fewer man-hours relative to other employment, and suggests the activity could be an attractive alternative livelihood should supply/demand allow. However, wildlife trapping was limited by many factors including seasonal and quota restrictions, animal availability, demand (orders), and opportunity cost (involvement in other activities, e.g., agriculture). This type of trade may also have limited ability to act as a risk-reduction strategy, because whereas households can adapt patterns of bushmeat consumption in response to lean seasons (e.g., SchulteHerbruggen et al. 2013), research along the supply chain in Madagascar (Robinson 2016) suggests the live animal trade in Madagascar is predominantly "collection to order" and therefore constrained by demand. Trappers' health was also mentioned as a limitation as was absence from home while travelling long distances. It was also perceived risky from a livelihood or economic perspective because of inconsistency and unreliability of orders and payments, and concern regarding legality. This insecurity may arise because some reptile and amphibian species are constrained by quotas or not permitted in trade, and these details may be unclear to people in rural areas. Additionally, local trappers are usually employed by intermediaries, who are required to carry collection permits, but there is no paperwork for trappers themselves. These limitations mean that wildlife collection is generally a supplementary activity, with most households preferentially allocating resources to agriculture. However, given that the households engaged in trapping appeared to be some of the poorest, trapping may support those with more limited alternative livelihood choices, providing important cash income. Family involvement was also a significant determinant, suggesting "who you know" to be an important entry point.

Because trapping households were significantly more likely to agree that traded wildlife groups were important for income compared to nontrappers, we might expect those benefitting financially to have more positive opinions regarding its conservation. However, despite generally positive perceptions regarding species and habitat conservation, there was no evidence of improved perceptions among wildlife trappers, suggesting trapping may not offer sufficient incentives to lead to enhanced stewardship of traded species and their habitats. However, wildlife is valued for both social and economic reasons (Brooks 2010), and perceptions toward conservation may be affected by other values besides economic use for trade, e.g., medicine or food. Additionally, although previous studies have shown that projects focused on enhancing commercial value of resources can improve attitudes toward conservation and provide economic incentives for resource protection (Salafsky and Wollenberg 2000), wildlife collection in this area is not currently managed as part of a specific incentive-based project, but is regulated under wider national and international legislation, e.g., CITES, concerning biodiversity conservation. This study therefore provides an understanding of the situation in areas outside of such targeted projects, which are arguably more representative of wider national and international landscapes where the majority of wildlife collection occurs.

In order to maximize conservation and livelihood benefits of wildlife trade a number of factors require combined consideration and our study constitutes part of a more complex picture. These factors include "species-level," "governance," "supply chain," and "end-market" factors (Cooney et al. 2015). Species-level factors include species suitability for harvest such as resilience and accessibility. For example, Madagascar's panther chameleon (Furcifer pardalis) is abundant in disturbed areas and appears to sustain collection for export (Andreone et al. 2005), whereas the harlequin mantella (Mantella cowanii) has a small population and its collection could lead to local extinction (Andreone et al. 2006). Governance factors include property rights and policy settings. In Madagascar, property rights are often poorly defined (Bojö et al. 2013) and without security of tenure over land and resource rights, there may be little incentive for local people to invest in long-term sustainability of the wildlife resource (Roe 2008). However, there are exceptions to this and in some cases users have been shown to develop rules that limit use of common resources in the absence of central resource control (Ostrom 2008). Supply chain factors include organization and operation of the supply chain including barriers to entry and supply chain length. In this case, the supply chain appeared poorly organized leading to mistrust between trappers and intermediaries, and concern over payments and legal paperwork. Finally, end-market factors include market size, demand elasticity, and consumer preferences. This illustrates the complex range of factors that require consideration in order to better understand the dimensions of wildlife supply chains and inform appropriate management. Research is ongoing to understand further aspects regarding benefits, and information flow along the entire supply chain in Madagascar. 


\section{CONCLUSION}

Although it was potentially profitable and provided cash income to some households as part of a diverse livelihood strategy, wildlife trapping was sporadic, and perceived to be unreliable and risky. Consequently, there is currently limited evidence that income from the trade creates incentives for wider species and habitat protection at the local scale in Madagascar. Further studies are required to understand if this is representative of other parts of Madagascar, and in other countries where collection for the pet trade occurs. Interventions aimed at enhancing benefits to local communities, improving coordination and management of the trade at the local level, and minimizing impacts on collected species, could be considered to promote opportunities from the trade. Improved understanding of the social and economic dimensions of wildlife trade supply chains is necessary if the global trade in wildlife is to be understood and appropriate legislation and management systems put in place.

Responses to this article can be read online at: http://www.ecologyandsociety.org/issues/responses. php/9821

\section{Acknowledgments:}

We thank research assistants: L. Raharinjanahary, $V$. Rakotomboavonjy, and $M$. Soazandry. We also thank $J$. Razafimanahaka, C. Randrianantoandro, R. Andriantsimanarilafy, G. Andrianantenaina, and the team at Madagasikara Voakajy for technical and logistic support; the Ministere de L'Environment, des Eaux et Forets, for research permits; and all respondents. This study was funded by a University of Kent PhD Scholarship, the Darwin Initiative (project 19-014), and a Conservation Research Grant from Chester Zoo.

\section{LITERATURE CITED}

Andreone, F., F. M. Guarino, and J. E. Randrianirina. 2005. Life history traits, age profile, and conservation of the panther chameleon, Furcifer pardalis (Cuvier 1829), at Nosy Be, NW Madagascar. Tropical Zoology 18:209-225. http://dx.doi. org/10.1080/03946975.2005.10531221

Andreone, F., V. Mercurio, and F. Mattioli. 2006. Between environmental degradation and international pet trade: conservation strategies for the threatened amphibians of Madagascar. Natura 95:81-96.

Baker, S. E., R. Cain, F. van Kesteren, Z. A. Zommers, N. D'Cruze, and D. W. Macdonald. 2013. Rough trade: animal welfare in the global wildlife trade. BioScience 63:928-938. http:// dx.doi.org/10.1525/bio.2013.63.12.6

Barrett, C. B., T. Reardon, and P. Webb. 2001. Nonfarm income diversification and household livelihood strategies in rural Africa: concepts, dynamics, and policy implications. Food Policy 26:315-331. http://dx.doi.org/10.1016/S0306-9192(01)00014-8

Barton, K. 2011. MuMIn: multi-model inference. R package, version 1.0. 0. R Foundation for Statistical Computing, Vienna, Austria.
Bennett, E. L. 2011. Another inconvenient truth: the failure of enforcement systems to save charismatic species. Oryx 45:476-479. http://dx.doi.org/10.1017/S003060531000178X

Bojö, J., K.-G. Mäler, and L. Unemo. 2013. Environment and development: an economic approach. Springer Science \& Business Media, Dordrecht, The Netherlands.

Brashares, J. S., C. D. Golden, K. Z. Weinbaum, C. B. Barrett, and G. V. Okello. 2011. Economic and geographic drivers of wildlife consumption in rural Africa. Proceedings of the National Academy of Sciences of the United States of America 108:13931-13936. http://dx.doi.org/10.1073/pnas.1011526108

Broad, S., T. Mulliken, and D. Roe. 2003. The nature and extent of legal and illegal trade in wildlife. Pages 3-22 in S. Oldfield, editor. The trade in wildlife: regulation for conservation. Earthscan, London, UK.

Brooks, J. S. 2010. Economic and social dimensions of environmental behavior: balancing conservation and development in Bhutan. Conservation Biology 24:1499-1509. http://dx.doi. org/10.1111/j.1523-1739.2010.01512.X

Burnham, K. P., and D. Anderson. 2002. Model selection and multi-model inference. A pratical information-theoretic approach. Springer, New York, New York, USA.

Carpenter, A., and O. Robson. 2008. Madagascan amphibians as a wildlife resource and their potential as a conservation tool: species and numbers exported, revenue generation and bioeconomic model to explore conservation benefits. Pages 357-376 in $\mathrm{F}$. Andreone, editor. A conservation strategy for the amphibians of Madagascar. Vol. 45. Monografie del Museo Regionale di Scienze Naturali, Torino, Italy.

Carpenter, A. I., J. M. Rowcliffe, and A. R. Watkinson. 2004. The dynamics of the global trade in chameleons. Biological Conservation 120:291-301. http://dx.doi.org/10.1016/j.biocon.2004.03.002

Carrete, M., and J. L. Tella. 2008. Wild-bird trade and exotic invasions: a new link of conservation concern? Frontiers in Ecology and the Environment 6:207-211. http://dx.doi. org/10.1890/070075

Challender, D. W. S., and D. C. MacMillan. 2014. Poaching is more than an enforcement problem. Conservation Letters 7:484-494. http://dx.doi.org/10.1111/conl.12082

Chomel, B. B., A. Belotto, and F.-X. Meslin. 2007. Wildlife, exotic pets, and emerging zoonoses. Emerging Infectious Diseases 13:6-11. http://dx.doi.org/10.3201/eid1301.060480

Chukwuone, N. A. 2009. Socioeconomic determinants of cultivation of non-wood forest products in southern Nigeria. Biodiversity and Conservation 18:339-353. http://dx.doi. org/10.1007/s10531-008-9489-y

Coad, L., K. Abernethy, A. Balmford, A. Manica, L. Airey, and E. J. Milner-Gulland. 2010. Distribution and use of income from bushmeat in a rural village, Central Gabon. Conservation Biology 24:1510-1518. http://dx.doi.org/10.1111/j.1523-1739.2010.01525. $\underline{\mathrm{x}}$

Convention on Biological Diversity (CBD). 2014. Convention on Biological Diversity. Secretariat of the Convention on Biological 
Diversity, Montréal, Québec, Canada. [online] URL: http://www. cbd.int

Convention on International Trade in Endangered Species (CITES). 2016. Convention on International Trade in Endangered Species. CITES, Geneva, Switzerland. [online] URL: http://www. cites.org

Cooney, R., and P. Jepson. 2006. The international wild bird trade: what's wrong with blanket bans? Oryx 40:18-23. http://dx.doi. org/10.1017/S0030605306000056

Cooney, R., A. Kasterine, D. W. Macdonald, S. Milledge, K. Nossal, D. Roe, and M. 't. Sas-Rolfes. 2015. The trade in wildlife: a framework to improve biodiversity and livelihood outcomes. International Trade Centre, Geneva, Switzerland.

de Merode, E., K. Homewood, and G. Cowlishaw. 2004. The value of bushmeat and other wild foods to rural households living in extreme poverty in Democratic Republic of Congo. Biological Conservation 118:573-581. http://dx.doi.org/10.1016/j.biocon.2003.10.005

Duffy, R., F. A. V. St. John, B. Büshcher, and D. Brockington. 2015. The militarization of anti-poaching: undermining long term goals? Environmental Conservation 42:345-348. http://dx. doi.org/10.1017/S0376892915000119

Duffy, R., F. A. V. St. John, B. Büscher, and D. Brockington. 2016. Toward a new understanding of the links between poverty and illegal wildlife hunting. Conservation Biology 30:14-22. http://dx. doi.org/10.1111/cobi.12622

Fa, J. E., J. Juste, R. W. Burn, and G. Broad. 2002. Bushmeat consumption and preferences of two ethnic groups in Bioko Island, West Africa. Human Ecology 30:397-416. http://dx.doi. org/10.1023/A:1016524703607

Golden, C. D., R. W. Wrangham, and J. S. Brashares. 2013. Assessing the accuracy of interviewed recall for rare, highly seasonal events: the case of wildlife consumption in Madagascar. Animal Conservation 16:597-603. http://dx.doi.org/10.1111/ acv. 12047

Gordon, I., and W. Ayiemba. 2003. Harnessing butterfly biodiversity for improving livelihoods and forest conservation: the Kipepeo Project. Journal of Environment \& Development 12:82-98. http://dx.doi.org/10.1177/1070496502250439

Harper, G. J., M. K. Steininger, C. J. Tucker, D. Juhn, and F. Hawkins. 2007. Fifty years of deforestation and forest fragmentation in Madagascar. Environmental Conservation 34:325-333. http://dx.doi.org/10.1017/S0376892907004262

Hutton, J. M., and N. Leader-Williams. 2003. Sustainable use and incentive-driven conservation: realigning human and conservation interests. Oryx 37:215-226. http://dx.doi.org/10.1017/S0030605303000395

Jepson, P., R. J. Ladle, and Sujatnika. 2011. Assessing marketbased conservation governance approaches: a socio-economic profile of Indonesian markets for wild birds. Oryx 45:482-491. http://dx.doi.org/10.1017/S003060531100038X

Jones, J. P. G., M. M. Andriamarovololona, N. Hockley, J. M. Gibbons, and E. J. Milner-Gulland. 2008. Testing the use of interviews as a tool for monitoring trends in the harvesting of wild species. Journal of Applied Ecology 45:1205-1212. http://dx. doi.org/10.1111/j.1365-2664.2008.01487.x
Karesh, W. B., R. Cook, E. L. Bennett, and J. Newcomb. 2005. Wildlife trade and global disease emergence. Emerging Infectious Diseases 11:1000-1002. http://dx.doi.org/10.3201/eid1107.050194

Kenney, J. S., J. L. D. Smith, A. M. Starfield, and C. W. McDougal. 1995. The long-term effects of tiger poaching on population viability. Conservation Biology 9:1127-1133. http://dx.doi. org/10.1046/j.1523-1739.1995.9051116.X-i1

Kümpel, N. F., E. J. Milner-Gulland, G. Cowlishaw, and J. M. Rowcliffe. 2010. Incentives for hunting: the role of bushmeat in the household economy in rural Equatorial Guinea. Human Ecology 38:251-264. http://dx.doi.org/10.1007/s10745-010-9316-4

Kusters, K., R. Achdiawan, B. Belcher, and M. Ruiz Pérez. 2006. Balancing development and conservation? An assessment of livelihood and environmental outcomes of nontimber forest product trade in Asia, Africa, and Latin America. Ecology and Society 11(2):20. http://dx.doi.org/10.5751/ES-01796-110220

Lybbert, T. J., A. Aboudrare, D. Chaloud, N. Magnan, and M. Nash. 2011. Booming markets for Moroccan argan oil appear to benefit some rural households while threatening the endemic argan forest. Proceedings of the National Academy of Sciences of the United States of America 108:13963-13968. http://dx.doi. org/10.1073/pnas. 1106382108

Ministere de l'Environment. 2006. Manuel de procedures pour la gestation de la faune et de la flore sauvages de Madagascar. Ministere de l'Environment, des Eaux et Forets, Direction Generale des Eaux et Forets, Antananarivo, Madagascar.

Morris, S. S., C. Carletto, J. Hoddinott, and L. J. M. Christiaensen. 2000. Validity of rapid estimates of household wealth and income for health surveys in rural Africa. Journal of Epidemiology and Community Health 54:381-387. http://dx.doi.org/10.1136/ jech.54.5.381

Myers, N., R. A. Mittermeier, C. G. Mittermeier, G. A. B. da Fonseca, and J. Kent. 2000. Biodiversity hotspots for conservation priorities. Nature 403:853-858. http://dx.doi.org/10.1038/35002501

Ostrom, E. 2008. Tragedy of the commons. Pages 1-5 in S. N. Durlauf and L. E. Blume, editors. The New Palgrave dictionary of economics. Palgrave Macmillan, London, UK. http://dx.doi. org/10.1057/978-1-349-95121-5_2047-1

R Core Team. 2015. R: A language and environment for statistical computing. R Foundation for Statistical Computing, Vienna, Austria.

Rabemananjara, F. C. E., N. Rasoamampionona Raminosoa, O. Ravoahangimala Ramilijaona, D. Rakotondravony, F. Andreone, P. Bora, A. Carpenter, F. Glaw, T. Razafindrabe, D. Vallan, D. R. Vieites, and M. Vences. 2008. Malagasy poison frogs in the pet trade: a survey of levels of exploitation of species in the genus Mantella. Pages 277-299 in F. Andreone, editor. A conservation strategy for the amphibians of Madagascar. Vol. 45. Monografie del Museo Regionale di Scienze Naturali, Torino, Italy.

Robinson, J. E. 2016. Supplying the exotic pet trade: conservation and livelihood implications. Dissertation. University of Kent, UK.

Robinson, J. E., R. A. Griffiths, F. A. V. St. John, and D. L. Roberts. 2015. Dynamics of the global trade in live reptiles: 
shifting trends in production and consequences for sustainability. Biological Conservation 184:42-50. http://dx.doi.org/10.1016/j. biocon.2014.12.019

Robinson, J. G., and K. H. Redford. 1991. Neotropical wildlife use and conservation. University of Chicago Press, Chicago, Illinois, USA.

Roe, D. 2008. Trading nature: a report, with case studies, on the contribution of wildlife trade management to sustainable livelihoods and the Millennium Development Goals. TRAFFIC International, Cambridge, UK.

Roe, D., R. Cooney, H. Dublin, D. Challender, D. Biggs, D. Skinner, M. Abensperg-Traun, N. Ahlers, R. Melisch, and M. Murphree. 2015. Beyond enforcement: engaging communities in tackling wildlife crime. IIED, London, UK.

Roe, D., T. Mulliken, S. Milledge, J. Mremi, S. Mosha, and M. Grieg-Gran. 2002. Making a killing or making a living: wildlife trade, trade controls, and rural livelihoods. Biodiversity and Livelihoods Issue No. 6. IIED and TRAFFIC. London, UK.

Rosen, G. E., and K. F. Smith. 2010. Summarizing the evidence on the international trade in illegal wildlife. EcoHealth 7:24-32. http://dx.doi.org/10.1007/s10393-010-0317-y

Salafsky, N., and E. Wollenberg. 2000. Linking livelihoods and conservation: a conceptual framework and scale for assessing the integration of human needs and biodiversity. World Development 28:1421-1438. http://dx.doi.org/10.1016/S0305-750X(00)00031-0

Schulte-Herbruggen, B., G. Cowlishaw, K. Homewood, and J. M. Rowcliffe. 2013. The importance of bushmeat in the livelihoods of West African cash-crop farmers living in a faunally-depleted landscape. PLoS One 8:e72807. http://dx.doi.org/10.1371/ journal.pone.0072807

Spiteri, A., and S. K. Nepalz. 2006. Incentive-based conservation programs in developing countries: a review of some key issues and suggestions for improvements. Environmental Management 37:1-14. http://dx.doi.org/10.1007/s00267-004-0311-7

Symonds, M. R. E., and A. Moussalli. 2011. A brief guide to model selection, multimodel inference and model averaging in behavioural ecology using Akaike's information criterion. Behavioral Ecology and Sociobiology 65:13-21. http://dx.doi. org/10.1007/s00265-010-1037-6

The World Bank. 2016. Poverty \& equity. Country dashboard: Madagascar. The World Bank, Washington, D.C., USA. [online] URL: http://povertydata.worldbank.org/poverty/country/MDG

United Nations Development Programme (UNDP). 2015. Human development report 2015. UNDP, New York, New York, USA. [online] URL: http://www.undp.org/content/undp/en/ home/librarypage/hdr/2015-human-development-report/

United Nations Environment World Conservation Monitoring Centre (UNEP-WCMC). 2018. CITES trade data dashboards: global trade in amphibians. UNEP-WCMC, Cambridge, UK. [online] URL: http://dashboards.cites.org/global?id=Amphibians

Vitousek, P. M., C. M. Dantonio, L. L. Loope, and R. Westbrooks. 1996. Biological invasions as global environmental change. American Scientist 84:468-478.
XE. 2016. XE Currency Table: MGA - Malagasy Ariary. XE, Newmarket, Ontario, Canada. [online] URL: http://www.xe.com/ 
Appendix 1. Extended methodology.

\section{Household Livelihood Return (HLR)}

In order to calculate the total time households spent engaged in a given activity, respondents were asked which months the activity was carried out, the average number of days per week, and the hours per day spent for each activity. Total time was calculated by multiplying the number of hours per day, the number of days per week and the number of weeks per year. In the case of wildlife trapping, which was a more 'opportunistic' activity, total time was calculated by multiplying the number of hours per day, the number of days per order and the total number of orders received in a period.

Revenue was calculated by asking respondents the amount of produce per period (e.g. $50 \mathrm{~kg}$ rice), the market value of that produce (e.g. $1 \mathrm{~kg}$ rice=900 MGA/0.39 USD) and the average percentage of produce that was sold in that period. For wildlife trapping, respondents were asked the average amount of money they received per order, and this was multiplied by the number of orders in a period.

When assessing costs, respondents were asked to differentiate start-up costs, which were the costs associated with the first time they did an activity (e.g. purchase or loan of land), and ongoing variable costs (excluding fixed costs), which were those associated with continuing the activity (e.g. fertiliser, seed), and the frequency each cost was incurred (e.g. fertiliser once per year). The ongoing costs (excluding fixed costs e.g. purchase of land) were used in the HLR analysis.

Throughout the analysis, where a range of values was given e.g. 5-10 hours, then the midvalue was used (i.e. 7.5). This was used to calculate median and IQR. Median values were also used in cases of missing price data, for example if one person failed to report the market price of their agricultural produce, then the median value according to all the other respondents was used. For wildlife trapping, where specific information on the number of hours worked per day was missing, then a median value of six hours calculated from respondents who did give the information was used. In cases where respondents stated 'an entire night', then an entire night was presumed to be 10 hours (e.g. 8 pm to 6 am). 
Table A1.1. Household asset bundle including the number and percentage of households that owned each item. The asset bundle ranged from inexpensive to expensive physical items, and livestock. This list was used to create a household asset index based on Morris et al. (2000) where an index is calculated for each household based on the quantity of a particular asset the household in question owns, and the proportion of households owning that asset. Livestock were included given their local importance regarding wealth. Data from systematic sample only.

\begin{tabular}{lll}
\hline Item & $n$ & \% Households \\
& & (valid \%, excl missing answers) \\
\hline cooking pot & 231 & 100.0 \\
mattress (filled rice sack) & 208 & 91.2 \\
shovel & 231 & 99.1 \\
bed & 205 & 88.7 \\
lamp (kerosene) & 203 & 88.6 \\
table & 190 & 83.3 \\
radio & 190 & 82.3 \\
chair & 183 & 80.3 \\
lamp (battery/electric) & 153 & 66.8 \\
clock & 120 & 51.9 \\
bicycle & 111 & 47.8 \\
mobile phone & 97 & 42.7 \\
watch & 60 & 25.1 \\
mattress (foam) & 51 & 22.0 \\
plough & 53 & 22.8 \\
charcoal stove & 52 & 22.5 \\
music player (CD/DVD) & 42 & 18.3 \\
television & 40 & 17.3 \\
generator (battery/electric) & 30 & 12.9 \\
motorbike & 8 & 3.5 \\
Motor cultivator & 5 & 2.2 \\
solar stove & 1 & 0.4 \\
car & 1 & 0.4 \\
\hline chicken & 180 & 79.3 \\
zebu & 67 & 28.6 \\
pig & 52 & 22.3 \\
\hline
\end{tabular}




\section{Appendix 2. Summary of livelihood activities.}

Table A2.1. Summary of livelihood and subsistence activities carried out by 240 systematically sampled households $(\mathrm{HH})$, including the number and percentage of households involved in each activity.

\begin{tabular}{|c|c|c|}
\hline Livelihood and Subsistence Activity & 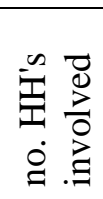 & 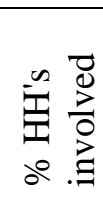 \\
\hline Collecting animals for trade (reptiles, amphibians \& invertebrates) & 32 & 13.3 \\
\hline Hunting \& gathering & 82 & 34.2 \\
\hline collecting animals for food (tenrecs, edible frogs, fish, shrimps) & 10 & 4.2 \\
\hline collecting plant products for food/medicine/use (e.g. wild black nightshade) & 42 & 17.5 \\
\hline firewood collection (mostly domestic use, occasionally for sale) & 52 & 21.7 \\
\hline Other (collecting honey, charcoal) & 12 & 5.0 \\
\hline Cultivation (listing those where $>5 \%$ of people are involved) & 234 & 97.5 \\
\hline lowland rice & 214 & 89.2 \\
\hline cassava & 214 & 89.2 \\
\hline sweet potatoes & 146 & 60.8 \\
\hline beans & 127 & 52.9 \\
\hline corn & 118 & 49.2 \\
\hline banana & 102 & 42.5 \\
\hline leaf vegetables & 72 & 30.0 \\
\hline ginger & 62 & 25.8 \\
\hline taro & 57 & 23.8 \\
\hline upland rice & 51 & 21.3 \\
\hline Bambara groundnuts & 53 & 22.1 \\
\hline peanuts & 50 & 20.8 \\
\hline irrigated rice & 28 & 11.7 \\
\hline pineapples & 23 & 9.6 \\
\hline sugar cane & 14 & 5.8 \\
\hline other cultivation ${ }^{\dagger}$ & 43 & 17.9 \\
\hline Livestock keeping ( $>5 \%$ of people involved) & 184 & 76.7 \\
\hline chicken/laying hens & 159 & 66.3 \\
\hline oxen/cows & 66 & 27.5 \\
\hline pigs & 58 & 24.2 \\
\hline ducks/Muscovy ducks & 56 & 23.3 \\
\hline geese & 29 & 12.1 \\
\hline other livestock ${ }^{\ddagger}$ & 18 & 7.5 \\
\hline Farm labour (e.g. sowing, ploughing) & 35 & 14.6 \\
\hline Non-farm labour & 71 & 29.6 \\
\hline trading produce/goods (e.g. livestock, harvest, charcoal) & 23 & 12.1 \\
\hline shop, restaurant, pub & 10 & 4.2 \\
\hline handicrafts (plaiting mats, weaving baskets) & 9 & 3.8 \\
\hline other employment and self-employment ${ }^{\S}$ & 43 & 21.0 \\
\hline
\end{tabular}


'chayote, 'ovy tsatoka' (root vegetable), potatoes, coffee, avocado, pumpkin, carrots, cucumber, zucchini, cabbage, cress, green beans, black-eyed beans, peas, cauliflower, spices, sorghum, orange, papaya, mango, litchi, peach, persimmon.

poultry (unspecified), guinea pigs, turkey, goats, rabbits, gamecocks, pigeons.

§goldmining, selling cooked rice to miners, cook, making rum, laundry, butcher, photography, guide, mechanic, carrier, masonry, bricklayer, carpenter, dress maker, woodcutter, babysitter, house guard, truck driver, working in Ambatovy mine, teacher, pastor, secretary of commune, JIRAMA, VOI member, pension, house trade, cart rental, field rental. 
Appendix 3. Demographic information

Households consisted of one to 11 household members (median=5, IQR=2, $n=240$ ). The median age of the household head was $45(\mathrm{IQR}=20, \mathrm{n}=237)$ and $65.0 \%(\mathrm{n}=156)$ were male. A large proportion of respondents had partially or completed primary education $(66.3 \%$, $\mathrm{n}=159)$, whilst $21.3 \%(\mathrm{n}=51)$ had some secondary education and $12.5 \%(\mathrm{n}=30)$ had no education at all. The majority $(86.5 \%, \mathrm{n}=205)$ of respondents were born within the district of Moramanga, whilst the remaining $13.5 \%(\mathrm{n}=32)$ had migrated into the area from another district. Most $(74.7 \%, \mathrm{n}=177)$ were Benzanozano or Benzanozano mixed ethnicity, $13.1 \%$ $(n=31)$ were Merina or Merina mixed ethnicity and the remainder $(12.2 \% n=29)$ belonged to other ethnicities including Antandroy, Antanosy-Merina, Betsileo, Betsimisaraka, St Marians, Sakalava and Sihinaka. The table below shows demographic parameters broken down for trapping and non-trapping households.

Table A3.1. Selected demographic information for systematically sampled non-trapping households (HHs), wildlife trapping households and households only involved in trapping reptiles and amphibians.

\begin{tabular}{|c|c|c|c|}
\hline & $\begin{array}{l}\text { Non-trapper HHs } \\
(n=208) \dagger\end{array}$ & $\begin{array}{l}\text { All trapper HHs } \\
(n=32) \dagger\end{array}$ & $\begin{array}{l}\text { Subset: Reptile \& } \\
\text { amphibian trapper HHs } \\
(n=13) \dagger\end{array}$ \\
\hline $\begin{array}{l}\text { Household } \\
\text { size }\end{array}$ & median $=5, \mathrm{IQR}=2.8$ & median $=4.5, \mathrm{IQR}=1.8$ & median=5, IQR=3.5 \\
\hline \multirow[t]{3}{*}{ Education } & Primary $67.3 \%,(n=140)$ & Primary $59.4 \%(n=19)$ & Primary $61.5 \%(n=8)$ \\
\hline & Secondary $21.2 \%,(n=44)$ & Secondary $21.9 \%(n=7)$ & Secondary $15.4 \%(n=2)$ \\
\hline & none $=11.5 \%(\mathrm{n}=24)$ & none $18.8 \%(n=6)$ & None $11.9 \%(n=3)$ \\
\hline \multirow[t]{2}{*}{ Residency } & Resident $86.8 \%(\mathrm{n}=178)$ & Resident $84.4 \%(\mathrm{n}=27)$ & Resident $69.2 \%(\mathrm{n}=9)$ \\
\hline & Migrant $13.2 \%(n=27)$ & Migrant $15.6 \%(n=5)$ & Migrant $30.8 \%(n=4)$ \\
\hline \multirow[t]{7}{*}{ Ethnicity } & $\begin{array}{l}\text { Bezanozano or Bezanozano } \\
\text { mixed: } 74.1 \%(n=154)\end{array}$ & $\begin{array}{l}\text { Bezanozano or } \\
\text { Bezanozano mixed: } \\
71.9 \%(n=23)\end{array}$ & Bezanozano: $53.8 \%(n=7)$ \\
\hline & $\begin{array}{l}\text { Merina or Merina mixed: } \\
14.0 \%(\mathrm{n}=29)\end{array}$ & Antandroy $(\mathrm{n}=1)$ & Antanosy-Merina $(\mathrm{n}=1)$ \\
\hline & Betsileo $(n=5)$ & Antanosy $(\mathrm{n}=1)$ & \\
\hline & Betsimisaraka $(\mathrm{n}=9)$ & Betsileo $(n=1)$ & Betsileo (n=1) \\
\hline & St Marians $(\mathrm{n}=1)$ & Betsimisaraka $(n=4)$ & Betsimisiraka $(n=3)$ \\
\hline & Sakalava $(\mathrm{n}=1)$ & Merina $(n=2)$ & Sihanaka $(\mathrm{n}=1)$ \\
\hline & Sihanaka $(n=6)$ & Sihanaka $(\mathrm{n}=1)$ & \\
\hline $\begin{array}{l}\text { Yrs lived in } \\
\text { village }\end{array}$ & median $=27, \mathrm{IQR}=27, \mathrm{n}=199$ & median $=25, \mathrm{IQR}=28.3$ & median=30, IQR $=33.5$ \\
\hline
\end{tabular}


median=8, IQR=5

median $=10.5, \mathrm{IQR}=4$

median $==9, \mathrm{IQR}=3.5$

activities

No.

median=2, IQR=1

median $=3, \mathrm{IQR}=1$

median $=3, \mathrm{IQR}=1$

livelihood

categories

†unless otherwise indicated within table 


\section{Appendix 4. Uses of income from wildlife trapping}

Trappers used the income from reptile and amphibian collection for a number of purposes, the most frequently listed being subsistence purchases (e.g. sugar, salt, coffee, rice), which was listed by $57.1 \%$ of trappers $(n=16)$, followed by children's schooling (fees and equipment, $28.6 \%, \mathrm{n}=8)$. Other uses of income from collection included clothes $(17.9 \%$, $n=5$ ), agricultural costs (e.g. seeds, salary, 10.7\%, $n=3$ ), fuel (kerosene, batteries, $n=2$ ), personal needs (pocket money, games, $n=2$ ) and 'other' (rent, emergencies, $n=3$ ).

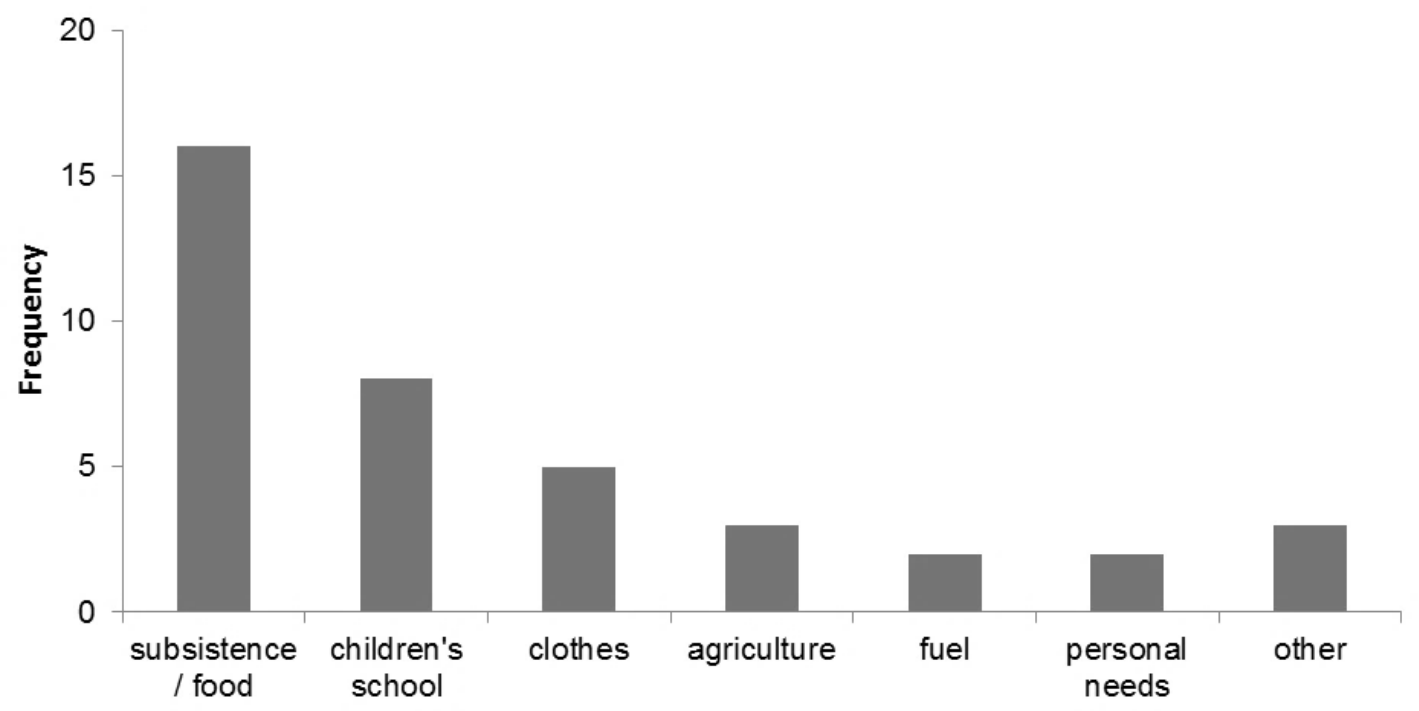

Figure A4.1. Uses of income earned from reptile and amphibian collection. Bars represent the frequencies of reported uses of wildlife collection income including subsistence (sugar, salt, coffee, rice), children's school (fees, tools), clothes, agriculture (seeds, salary), fuel (kerosene, batteries), personal needs (pocket money, games) and other $(n=28)$. 


\section{Appendix 5}

Table A5.1. Evaluation of 'Household Livelihood Return' (HLR) for livelihood activities carried out by households in the Moramanga district of Madagascar.

\begin{tabular}{|c|c|c|c|c|c|c|c|c|c|c|}
\hline \multirow[t]{2}{*}{ Livelihood Activity } & \multirow{2}{*}{$\begin{array}{l}\text { \% sold } \\
\text { Median } \\
(\mathrm{Q} 1, \mathrm{Q} 3)\end{array}$} & \multirow{2}{*}{$\begin{array}{l}\text { Revenue (USD) } \\
\text { Median } \\
\text { (Q1, Q3) }\end{array}$} & \multirow{2}{*}{$\begin{array}{l}\text { Costs } \\
\text { (USD) } \\
\text { Median } \\
(\text { Q1, Q3) }\end{array}$} & \multirow{2}{*}{$\begin{array}{l}\text { Net Income } 1 \\
\text { (USD) } \\
\text { Median } \\
(\mathrm{Q} 1, \mathrm{Q} 3)\end{array}$} & \multirow{2}{*}{$\begin{array}{l}\text { Net Income } \\
2 \text { (USD) } \\
\text { Median } \\
\text { (Q1, Q3) }\end{array}$} & \multirow[t]{2}{*}{$\begin{array}{l}\text { Total hours } \\
\text { Median (Q1, Q3) }\end{array}$} & \multicolumn{2}{|l|}{$\begin{array}{l}\text { HLR1 } \\
\text { Median (Q1, Q3) }\end{array}$} & \multicolumn{2}{|l|}{$\begin{array}{l}\text { HLR2 } \\
\text { Median (Q1, Q3) }\end{array}$} \\
\hline & & & & & & & USD/hr & $n$ & USD/hr & $n$ \\
\hline \multicolumn{11}{|l|}{ HLR2 $\geq \$ 0.5$ per hour } \\
\hline R\&A trapping & 100 & $114(84,217)$ & $12(0,55)$ & $105(64,192)$ & $105(64,192)$ & $162(97,343)$ & $0.7(0.47,1.81)$ & 28 & $0.7(0.47,1.81)$ & 28 \\
\hline Pineapple & $100(80,100)$ & $180(61,317)$ & $0(0,2)$ & $171(64,375)$ & $152(61,303)$ & $180(108,300)$ & $0.5(0.28,2.65)$ & 20 & $0.5(0.28,2.61)$ & 19 \\
\hline \multicolumn{11}{|l|}{ HLR2 $\geq \$ 0.1$ per hour } \\
\hline Geese & $75(50,88)$ & $92(59,203)$ & $0(0,0)$ & $92(58,203)$ & $81(24,154)$ & $182(91,455)$ & $0.4(0.18,1.13)$ & 25 & $0.3(0.06,0.74)$ & 23 \\
\hline Daily farm labour & NA & $111(33,223)$ & $0(0,0)$ & $111(33,223)$ & $111(33,223)$ & $526(263,1334)$ & $0.2(0.13,0.27)$ & 21 & $0.2(0.13,0.27)$ & 21 \\
\hline Chicken/laying & $43(0,75)$ & $86(37,186)$ & $0(0,0)$ & $73(28,182)$ & $17(0,64)$ & $91(61,182)$ & $0.5(0.20,1.70)$ & 121 & $0.1(0.00,0.75)$ & 125 \\
\hline \multicolumn{11}{|l|}{ hens } \\
\hline Bananas & $90(50,100)$ & $51(17,143)$ & $0(2,0)$ & $51(14,114)$ & $26(2,90)$ & $156(68,520)$ & $0.2(0.05,0.68)$ & 68 & $0.1(0.00,0.52)$ & 75 \\
\hline Pigs & $100(50,100)$ & $148(68,290)$ & $25(2,67)$ & $125(18,236)$ & $60(4,127)$ & $364(182,727)$ & $0.3(0.06,0.74)$ & 44 & $0.1(0.01,0.27)$ & 41 \\
\hline Beans & $50(26,80)$ & $65(34,141)$ & $4(0,13)$ & $60(24,138)$ & $20(0,64)$ & $336(169,548)$ & $0.2(0.06,0.57)$ & 102 & $0.1(0.00,0.26)$ & 108 \\
\hline Peanuts & $50(0,75)$ & $24(13,43)$ & $2(0,4)$ & $21(12,34)$ & $11(-0,24)$ & $113(45,192)$ & $0.2(0.08,0.50)$ & 25 & $0.1(0.00,0.22)$ & 30 \\
\hline \multicolumn{11}{|l|}{ HLR $2<\$ 0.1$ per hour } \\
\hline Ducks/Muscovy & $58(0,100)$ & $43(24,75)$ & $0(0,0)$ & $41(24,78)$ & $10(0,42)$ & $182(91,364)$ & $0.2(0.11,0.65)$ & 42 & $0.0(0.00,0.22)$ & 43 \\
\hline Ginger & $80(73,100)$ & $43(21,88)$ & $0(0,10)$ & $29(13,60)$ & $26(4,54)$ & $606(277,1143)$ & $0.1(0.02,0.15)$ & 51 & $0.0(0.00,0.13)$ & 51 \\
\hline $\begin{array}{l}\text { Bambara } \\
\text { groundnut }\end{array}$ & $67(27,90)$ & $39(15,86)$ & $3(0,9)$ & $30(13,77)$ & $9(0,51)$ & $494(260,870)$ & $0.1(0.02,0.17)$ & 38 & $0.0(0.00,0.07)$ & 41 \\
\hline Irrigated rice & $10(0,37)$ & $206(108,459)$ & $27(13,53)$ & $167(57,327)$ & $-1.9(-20,33)$ & $970(740,1377)$ & $0.1(0.40,0.62)$ & 38 & $0.0(-0.01,0.04)$ & 29 \\
\hline Leaf vegetables & $50(15,75)$ & $11(6,18)$ & $1(0,2)$ & $11(6,16)$ & $0(-0,8)$ & $208(78,424)$ & $0.0(0.00,0.09)$ & 39 & $0.0(-0.01,0.04)$ & 40 \\
\hline Corn & $25.0(0,73)$ & $17(8,38)$ & $0(0,1)$ & $13.3(5,36)$ & $0(0,13)$ & $364(152,727)$ & $0.1(0.02,0.13)$ & 86 & $0.0(0.00,0.04)$ & 107 \\
\hline Taro & $0(0,50)$ & $17(10,26)$ & $0(0,0)$ & $17(6,25)$ & $0(0,6)$ & $540(234,940)$ & $0.0(0.00,0.04)$ & 34 & $0.0(0.00,0.01)$ & 43 \\
\hline Cassava & $0(0,50)$ & $21(11,45)$ & $0(0,4)$ & $21(7,43)$ & $0(-1,4)$ & $831(468,1559)$ & $0.0(0.01,0.06)$ & 111 & $0.0(-0.00,0.01)$ & 160 \\
\hline
\end{tabular}




\begin{tabular}{|c|c|c|c|c|c|c|c|c|c|c|}
\hline Sweet potato & $0(0,5)$ & $9(4,24)$ & $0(0,0)$ & $9(4,23)$ & $0(0,0)$ & $260(128,520)$ & $0.0(0.01,0.09)$ & 72 & $0.0(0.00,0.00)$ & 126 \\
\hline Oxen/cows & $0.0(0,0)$ & $867(578,1413)$ & $26(13,70)$ & $727(445,1228)$ & $-25(-41,-13)$ & $2182(1819,2448)$ & $0.3(0.15,0.54)$ & 42 & $-0.0(-0.03,-0.01)$ & 39 \\
\hline Upland rice & $0(0,25)$ & $105(48,255)$ & $26(6,64)$ & $63(6,189)$ & $-10(-39,-1)$ & $909(646,1221)$ & $0.1(0.01,0.25)$ & 47 & $-0.0(-0.05,0.00)$ & 45 \\
\hline Lowland rice & $10(0,30)$ & $216(105,409)$ & $23(9,51)$ & $157(70,324)$ & $-5(-27,27)$ & $1039(695,1364)$ & $0.2(0.08,0.41)$ & 194 & $-0.0(0.03,0.03)$ & 199 \\
\hline
\end{tabular}

$†$ Economic information presented includes median (first quartile, third quartile): percentage of produce sold ('\% sold'), 'revenue', 'costs', 'net income' (revenue - costs) and 'HLR'. 'Revenue' does not consider percentage sold and therefore indicates the total monetary value if $100 \%$ of produce was sold. 'Net income 1' is calculated without incorporating percentage sold. 'Net Income 2' is adjusted to account for percentage sold. HLR1 is calculated from 'net income 1 ' divided by 'total hours' in order to give 'value per unit of effort' (USD/hour). 'HLR 2' is calculated from 'Net income 2' (therefore incorporating percentage sold). Time information includes the median (first quartile, third quartile) total number of hours the activity is carried out per year, calculated from information on months per year, days per week, and hours per day. R\&A trapping=reptile and amphibian trapping. 
Appendix 6. Perceptions towards wildlife

Table A6.1. Evaluation of respondent's agreement scores with various statements concerning values of traded and non-traded wildlife groups.

\begin{tabular}{|c|c|c|c|c|c|c|c|c|c|c|c|c|c|}
\hline \multicolumn{14}{|c|}{ For each animal group please indicate how much YOU agree or disagree with the following statements: } \\
\hline & \multicolumn{5}{|c|}{$\begin{array}{l}\text { I think that this animal is good for providing } \\
\text { money }\end{array}$} & \multicolumn{3}{|c|}{ I am afraid of this animal } & \multicolumn{5}{|c|}{$\begin{array}{l}\text { I think that this animal is important for the } \\
\text { environment }\end{array}$} \\
\hline & $n$ & $\begin{array}{l}\text { disagree } \\
(\%)\end{array}$ & $\begin{array}{l}\text { agree nor } \\
\text { disagree } \\
(\%)\end{array}$ & agre & $(\%)$ & $n$ & $\begin{array}{l}\text { disagree } \\
(\%)\end{array}$ & $\begin{array}{l}\text { agree nor } \\
\text { disagree } \\
(\%)\end{array}$ & agree $(\%)$ & $n$ & $\begin{array}{l}\text { disagree } \\
(\%)\end{array}$ & $\begin{array}{l}\text { agree nor } \\
\text { disagree } \\
(\%)\end{array}$ & agree $(\%)$ \\
\hline chameleons & 236 & 45.0 & 16.9 & 37.3 & & 236 & 37.7 & 0.8 & 61.4 & 236 & 3.8 & 8.9 & 87.3 \\
\hline geckoes & 236 & 49.6 & 16.1 & 34.3 & & 236 & 48.3 & 0.4 & 51.3 & 236 & 4.2 & 9.3 & 86.4 \\
\hline snakes & 236 & 55.5 & 22.9 & 21. & & 236 & 27.1 & 0.8 & 72.0 & 236 & 6.8 & 11.9 & 81.4 \\
\hline frogs & 236 & 47.5 & 17.8 & 34. & & 236 & 80.9 & 1.3 & 17.8 & 236 & 5.1 & 8.9 & 86.0 \\
\hline invertebrates & 236 & 57.2 & 15.7 & 27. & & 236 & 18.3 & 0.9 & 80.9 & 235 & 9.3 & 14.4 & 76.3 \\
\hline birds & 236 & 60.2 & 15.7 & 24 & & 236 & 88.1 & 1.7 & 10.2 & 236 & 3.8 & 6.4 & 89.8 \\
\hline lemurs & 236 & 53.0 & 17.4 & 29. & & 236 & 48.3 & 7.2 & 44.5 & 235 & 4.7 & 6.4 & 88.9 \\
\hline \multirow[t]{2}{*}{ tenrecs } & 236 & 56.4 & 16.1 & 27. & & 236 & 76.3 & 2.1 & 21.6 & 236 & 5.5 & 8.1 & 86.4 \\
\hline & & $\begin{array}{l}\text { I think th } \\
n\end{array}$ & $\begin{array}{l}\text { the current } \\
\text { elimin } \\
(\%)\end{array}$ & $\begin{array}{l}\text { numb } \\
\text { ted }\end{array}$ & $\begin{array}{l}\text { ers of this } \\
\text { reduced } \\
(\%)\end{array}$ & $\begin{array}{l}\text { mals shoul } \\
\text { kept at } \\
\text { same } \\
\text { level (\%) }\end{array}$ & $\begin{array}{l}\text { be: } \\
\text { increa } \\
(\%)\end{array}$ & & $\begin{array}{l}\text { I think the } \\
n\end{array}$ & $\begin{array}{l}\text { e natural hab } \\
\text { eliminated } \\
(\%)\end{array}$ & $\begin{array}{l}\text { tat should be } \\
\text { reduced } \\
(\%)\end{array}$ & $\begin{array}{l}\text { kept at } \\
\text { same } \\
\text { level }(\%)\end{array}$ & $\begin{array}{l}\text { increased } \\
(\%)\end{array}$ \\
\hline chameleons & & 236 & 2.1 & & 7.6 & 32.6 & 57.6 & & 83 & 0 & 1.2 & 32.5 & 66.3 \\
\hline geckoes & & 236 & 2.5 & & 5.5 & 30.5 & 61.4 & & & & & & \\
\hline snakes & & 236 & 7.6 & & 5.5 & 30.1 & 51.3 & & & & & & \\
\hline frogs & & 235 & 0.4 & & 6.0 & 24.3 & 69.4 & & & & & & \\
\hline invertebrates & & 236 & 10.6 & & 8.1 & 30.1 & 51.3 & & & & & & \\
\hline birds & & 236 & 0.4 & & 4.2 & 23.3 & 72.0 & & & & & & \\
\hline lemurs & & 236 & 0.8 & & 3.8 & 24.6 & 70.8 & & & & & & \\
\hline tenrecs & & 236 & 1.7 & & 10.2 & 18.2 & 69.9 & & & & & & \\
\hline
\end{tabular}

